International Research Journal of Management, IT \& Social Sciences
Available online at https://sloap.org/journals/index.php/irjmis/
Vol. 6 No. 4, July 2019, pages: 62 72
ISSN: 2395-7492
https://doi.org/10.21744/irjmis.v6n4.640

\title{
Capital Structure as A Mediation Variable: Profitability and Liquidity on Company Value in Real Estate Companies in Indonesia Stock Exchange
}

I Gede Wibawa Reska Putra ${ }^{\text {a }}$ Ida Bagus Panji Sedana ${ }^{\mathrm{b}}$

Article history:

Received: 27 March 2019

Accepted: 31 May 2019

Published: 9 June 2019

\section{Keywords:}

capital;

firm value;

liquidity;

profitability;

structure;

\begin{abstract}
The purpose of this study is to determine the effect of variable profitability, liquidity, and capital structure on the firm value in real estate companies listed on the Indonesia Stock Exchange (IDX). The population of this study is a real estate company listed on the Indonesia Stock Exchange (IDX) for the period 2013-2017. The method of determining the sample in this study used a purposive sampling method, with several predetermined criteria, then the number of selected samples was 26 companies. Data collection is done using the method of non-participant observation. The data analysis technique used is path analysis which is an extension of the multiple linear regression analysis techniques. Based on the results of the analysis of the study shows that the variables of profitability, liquidity, and capital structure have a positive and significant effect on firm value. The results of the Sobel test also show that the capital structure variable is able to mediate the relationship between profitability and liquidity towards firm value.
\end{abstract}

2395-7492@ Copyright 2019. The Author. This is an open-access article under the CC BY-SA license (https://creativecommons.org/licenses/by-sa/4.0/) All rights reserved.

\section{Author correspondence:}

I Gede Wibawa Reska Putra,

Faculty of Economics and Business, Udayana University, Denpasar, Indonesia

Jalan P.B. Sudirman, Dangin Puri Kelod, Denpasar, Bali 80234

Email address: wibawareska24@gmail.com

\section{Introduction}

The firm value is not only seen in terms of profitability but must also be seen from the side of liquidity. Company liquidity is indicated by the size of current assets, namely assets that are easily converted into cash, securities, accounts receivable, and supplies (Sartono, 2016). The liquidity ratio is used to measure a company's ability to fulfill its shortterm obligations. If a company is able to fulfill its obligations, it means the company is liquid, whereas if the company is unable to fulfill its obligations, it means the company is liquid (Horne \& Wachowicz, 2014). In this study, the liquidity ratio is measured by the Current Ratio.

\footnotetext{
a Faculty of Economics and Business, Udayana University, Denpasar, Indonesia ${ }^{\mathrm{b}}$ Faculty of Economics and Business, Udayana University, Denpasar, Indonesia
} 
The current ratio will show the extent to which the company is able to cover its current liabilities through assets owned by the company in the hope that these assets can be converted into cash in the near future (Brigham $\&$ Daves, 2016). A high current ratio may indicate the presence of excessive cash compared to the level of need or the presence of excessive liquidity assets (such as inventory) that are excessive. According to Brigham \& Daves (2016), the high current ratio is indeed good from a creditor's point of view, but from an investor's point of view it is less profitable and will be a problem for the company because current assets are not used effectively and vice versa if the low current ratio is relatively riskier, but shows that management has operated current assets effectively.

The study was conducted by Cheung et al., (2015); Vo \& Hong (2016); Shammakhi \& Azita (2016); and Arggawal \& Purna (2017), the results of the study showed that liquidity measured by the current ratio had a positive and significant effect on firm value. This means that company management has the ability to fulfill its short-term obligations and use current assets effectively. In contrast to the results of the research conducted by Gharaibeh (2014); Winarto (2015); and Heryanto (2018); Aghara et al., 2018), the results showed that liquidity had a negative effect on firm value.

When running a business, company management is very dependent on funding issues. The business world is experiencing a slowdown or decline at this time. The slowdown or setback was caused by many financial institutions that experienced financial difficulties as a result of credit bottlenecks without taking into account past credit limits. Anticipating the occurrence of the risk, company financial managers must be careful in determining the capital structure that is expected to increase the firm value. According to Mogdiliani and Miller in Brigham \& Daves (2016), firm value is also determined by capital structure. The capital structure of a company is defined as a structure that will maximize the firm value (share price) of a company. Determining the optimal structure will certainly be very beneficial for the company.

Based on the capital structure theory, if the position of capital structure is above the optimal capital structure target, then any increase in debt will reduce the firm value. Determination of the target of optimal capital structure is one of the main tasks of company management (Brigham \& Daves, 2016). If it is wrong to determine the capital structure, it will have a broad impact on the company. If the company is too large to use debt, the burden that must be borne by the company is also greater. Companies that use debt too large will increase financial risk, namely the risk when the company cannot pay the interest expense or installments of its debt.

The use of debt as a source of corporate funding will involve an exchange between risk and return. If you use a large amount of debt, it will increase the risk borne by the shareholders, but conversely, if you use a lower amount of debt, it will increase the estimated return on equity (Brigham \& Daves, 2016). The trade-off theory predicts a positive relationship between capital structure and firm value. The essence of the trade-off theory in capital structure is to balance the benefits and sacrifices that arise as a result of using debt. As far as the benefits are greater, then the additional debt is still allowed, but if the sacrifice is due to the use of debt already greater, then the additional debt is not allowed. The trade-off theory has considered various factors such as corporate tax, bankruptcy costs, and personal tax, in explaining why a company chooses a particular capital structure (Husnan, 2016).

Research related to the effect of capital structure on firm value including research conducted by Winarto (2015); Hasbi (2015); Zeb \& Rashid (2016); Asif \& Bilal (2016); Yanti et al., 2019) and Rizki et al., (2018), the results showed that capital structure has a positive and significant effect on firm value. In contrast to the results of research conducted by Manurung et al., (2014); Loncan \& Joao (2014); and Osazuwa \& Ahmad (2015), the results showed that the negative capital structure had an effect on the firm value.

Based on previous research, the results are still inconsistent and the development of the property and real estate sector in Indonesia which has decreased or slowed in the last five years has motivated and attracted researchers to conduct research on the property and real estate sector listed on the Indonesia Stock Exchange (IDX). So in this study, the variables used are profitability, liquidity, capital structure, and firm value.

In this study capital structure is used as a mediating variable, where the researcher uses the capital structure as a mediation variable due to inconsistencies from previous studies. The first relationship between profitability and capital structure is done by Masnoon \& Anwar (2012); Ukaegbu \& Oino (2014); Liang et al., (2014); Acaravci (2015); Chadha \& Sharma (2015); Alipour et al., (2015); and Wasim et al., (2016), whose research results show that profitability has a positive and significant effect on capital structure, while the research was conducted by Mouamer (2011); Sheikh \& Wang (2011); Salehi \& Manesh (2012); Mostarac \& Petrovic (2013); Malinic et al., (2013); Shah et al., (2013); Lemma \& Negash (2013); Pattweekongka \& Napompech (2014); Mota \& Moreira (2014); Wahab \& Ramli (2014); Kumar \& Babu (2016); and Phooi M'ng et al., (2017), whose research results show that profitability negative effect facing capital structure. The second relationship between liquidity and capital structure is carried out by Ukaegbu \& Oino (2014); Wahab \& Ramli (2014); Dewi et al., (2017) and Alipour et al., (2015), where the results show that liquidity has a

Putra, I. G. W. R., \& Sedana, I. B. P. (2019). Capital structure as a mediation variable: Profitability and liquidity on company value in real estate companies in Indonesia stock exchange. International Research Journal of Management, IT and Social Sciences, 6(4), 62-72. https://doi.org/10.21744/irjmis.v6n4.640 
positive and significant effect on capital structure, while research conducted by Mouamer (2011); Sheikh \&Wang (2011); Malinic et al., (2013); Pattweekongka \& Napompech (2014); Mota \& Moreira (2014); and Chadha \& Sharma (2015), the results show that liquidity has a negative effect on capital structure .

\section{Literature Review}

\section{The Effect of Profitability on Firm value}

Pecking order theory states that "a company with a high level of profitability will have a low debt level because companies with high profitability have more internal funding sources". Companies prefer to use internal sources of funds or internal funding rather than external funding. High company profitability will have a positive impact or can increase firm value (Horne \& Wachowicz, 2014). Research conducted by Manurung et al., (2014); Hasbi (2015); Ozazuwa \& Ahmad (2015); Winarto (2015); Zeb \& Rashid (2016); Sucuahi \& Jay (2016); Pramanaswari et al., (2018) and Agustina \& Niswah (2016), the results show that profitability has a significant and positive effect on firm value, this shows the greater the profitability (ROE), the better the company's value. Based on these explanations, the hypothesis proposed is as follows:

H1: Profitability has a positive effect on firm value.

\section{The Effect of Liquidity on Firm value}

Pecking order theory states that "a company with a high level of liquidity will have a low level of short-term liabilities because companies with high liquidity are able to fulfill and pay off all of their short-term liabilities on time". Liquidity is expected to have a positive relationship with the firm value because the higher the liquidity, the fulfillment of short-term obligations is met and that will increase market confidence (Horne \& Wachowicz, 2014). In this study using the current ratio as a representation of company liquidity. The study was conducted by Cheung et al. (2015); Vo \& Hong (2016); Shammakhi \& Azita (2016); and Arggawal \& Purna (2017). The results showed that liquidity had a positive and significant effect on firm value. Based on these explanations, the hypothesis proposed is as follows:

H2: Liquidity has a positive effect on firm value.

\section{The Effect of Capital Structure on Firm value}

The trade-off theory assumes that the company's capital structure is the result of trade-offs from tax profits by using debt with costs that will arise as a result of using the debt. The essence of the trade-off theory in capital structure is to balance the benefits and sacrifices that arise as a result of using debt. If it has greater benefits, then the additional debt is still permitted, but if the sacrifice is due to the use of debt already greater, then the additional debt is not allowed (Husnan, 2016). If the management of the company is able to increase the value of shares, the firm value will also increase, but if the debt changes, then the capital structure will also change. Changes in capital structure will be beneficial for shareholders if the firm value increases. Research conducted by Winarto (2015); Hasbi (2015); Zeb \& Rashid (2016); Asif \& Bilal (2016); and Rizki et al., (2018), the results showed that the capital structure has a positive effect on firm value. Based on these explanations, the hypothesis proposed is as follows:

H3: Capital Structure has a positive effect on firm value.

\section{The Effect of Profitability on Capital Structure}

The trade-off theory assumes that companies may choose to make loans to receive benefits from interest payments on these loans which will save tax costs, by following this theory profitability is expected to have a positive relationship with the capital structure (Husnan, 2016). Research conducted by Masnoon \& Anwar (2012); Ukaegbu \& Oino (2014); Liang et al., (2014); Acaravci (2015); Chadha \& Sharma (2015); Alipour et al., (2015); and Wasim et al., (2016), the results of his research indicate that profitability has a positive and significant effect on capital structure. Based on these explanations, the hypothesis proposed is as follows:

H4: Profitability has a positive effect on Capital Structure. 


\section{The Effect of Liquidity on Capital Structure}

Every company has a source of internal capital functioning not only on profitability but also on liquidity. The tradeoff theory in Horne \& Wachowicz (2014), says that every company that has a high current ratio must take loans to prevent directors from taking or using current assets owned by the company for personal purposes, which shows implicitly that liquidity has a positive relationship with the structured capital. The greater the comparison between current assets and current debt, the higher the company's ability to cover its current liabilities (Horne \& Wachowicz, 2014). Based on research conducted by Ukaegbu \& Oino (2014); Wahab \& Ramli (2014); and Alipour et al., (2015), where the results show that liquidity has a positive and significant effect on capital structure. Based on these explanations, the hypothesis proposed is as follows:

H5: Liquidity has a positive effect on Capital Structure.

\section{The Effect of Profitability on Firm values through Capital Structure}

High profitability allows companies to finance investments and company operations from the company's internal capital. So that the impact on the low debt held by the company, but the trade-off theory assumes that the company may make loans in a certain amount, of which the company will receive benefits from interest payments on loans that will save tax costs and save tax costs will increase the profitability of the company. Research conducted by Manurung et al., (2014); Hasbi (2015); Ozazuwa \& Ahmad (2015); Winarto (2015); Zeb \& Rashid (2016); Sucuahi \& Jay (2016); and Agustina \& Niswah (2016), results also shows that profitability has a significant and positive effect on firm value. Masnoon \& Anwar (2012); Ukaegbu \& Oino (2014); Liang et al., (2014); Acaravci (2015); Chadha \& Sharma (2015); Alipour et al., (2015); and Wasim et al., (2016), the results of his research indicate that profitability has a positive and significant effect on capital structure. Based on these explanations, the hypothesis proposed is as follows:

H6: Profitability has a direct effect on Firm values through Capital Structure.

\section{The Effect of Liquidity on Firm values through Capital Structure}

The size of the company's liquidity means that the company has sufficient funds to finance operational activities and fulfill the company's short-term obligations. Pecking order theory states that "a company with a high level of liquidity will have a low level of short-term liabilities because companies with high liquidity are able to fulfill and pay off all of their short-term liabilities on time". The higher the liquidity, the fulfillment of short-term obligations is met (Horne \& Wachowicz, 2014). Research conducted by Cheung et al., (2015); Vo \& Hong (2016); Shammakhi \& Azita (2016); and Arggawal \& Purna (2017), results also show that liquidity has a positive and significant effect on firm value. The greater the liquidity (current ratio) owned by the company, the firm value will increase. A large current ratio can meet short-term obligations on the company and if the excess assets remain, they can be converted into other current assets such as buying inventory. Based on this explanation, the hypothesis proposed is as follows:

H7: Liquidity has a direct effect on Firm values through Capital Structure.

\section{Materials and Methods}

ICMD (Indonesian capital market directory) for 2013-2017, and websites from the Indonesia Stock Exchange: (www.idx.co.id). The population in this study are all property \& real estate companies registered in Bura Securities Indonesia in accordance with the publication of ICMD (Indonesian Capital Market Directory) and the Indonesia Stock Exchange. The total population is 46 property \& real estate companies, while the sample is part of the number and characteristics possessed by the population, so the sample in this study amounted to 26 companies. The data collection method used in this study is a non-participant observation method, which is carried out observations of the documents needed as research data. The data analysis method used in this study is Path Analysis. This method is used to test hypotheses one through seven.

Putra, I. G. W. R., \& Sedana, I. B. P. (2019). Capital structure as a mediation variable: Profitability and liquidity on company value in real estate companies in Indonesia stock exchange. International Research Journal of Management, IT and Social Sciences, 6(4), 62-72. https://doi.org/10.21744/irjmis.v6n4.640 


\section{Results and Discussions}

This study uses path analysis techniques to test the direct or indirect effect of Profitability (ROE) and Liquidity (CR) on Capital Structure (DER) and Firm value (PBV). The completion of the path analysis model is divided into two models, namely the first model effects Profitability (ROE) and Liquidity (CR) on Capital Structure (DER). The second model is the effect of Profitability (ROE), Liquidity (CR), and Capital Structure (DER) on Corporate Value (PBV).

Table 1

ANOVA

ANOVA

\begin{tabular}{|rl|r|r|r|r|r|}
\hline Model & & \multicolumn{1}{c|}{$\begin{array}{c}\text { Sum of } \\
\text { Squares }\end{array}$} & df & Mean Square & F & Sig. \\
\hline 1 & Regression & 3,559 & 2 & 1,780 & 9,582 &, $000^{\mathrm{a}}$ \\
& Residual & 23,587 & 127 &, 186 & & \\
& Total & 27,146 & 129 & & & \\
\hline
\end{tabular}

a. Predictors: (Constant), CR, ROE

b. Dependent Variable: DER

The results of the $F$ test obtained showed an $F$ value of 9.582 with a significance of $0,000<0.05$ (significance level used). This shows that ROE and CR have a simultaneous effect and significance on DER.

Table 2

Multiple Regression I

\section{Coefficients}

\begin{tabular}{|c|c|c|c|c|c|c|}
\hline \multirow{2}{*}{\multicolumn{2}{|c|}{ Model }} & \multicolumn{2}{|c|}{$\begin{array}{l}\text { Unstandardized } \\
\text { Coeff icients }\end{array}$} & \multirow{2}{*}{$\begin{array}{c}\begin{array}{c}\text { St andardized } \\
\text { Coeff icients }\end{array} \\
\text { Beta }\end{array}$} & \multirow[b]{2}{*}{$\mathrm{t}$} & \multirow[b]{2}{*}{ Sig. } \\
\hline & & B & Std. Error & & & \\
\hline & (Constant) & ,978 & ,097 & & 10,099 & ,000 \\
\hline & ROE & ,004 & ,002 & , 083 & 2,880 & ,002 \\
\hline & CR & , 090 & ,023 & ,331 & 3,865 & ,000 \\
\hline
\end{tabular}

a. Dependent Variable: DER

The Effect of ROE (X1) on DER (Y1) on property \& real estate companies listed on the IDX for the period 2013-2017 Based on Table 2, it is known that the significance value is $0.002<0.05$, then the hypothesis (H4) is accepted, this result indicates a significant effect between ROE to DER on property \& real estate companies listed on the IDX. The beta value of 0.083 shows a positive direction, this value means that ROE has a positive effect on DER. If the ROE in property \& real estate companies increases, then the DER in the BEI property \& real estate companies listed decreases or the company chooses to use the loan but with a small amount.

This result is in line with the pecking order theory which states that a company with a high level of profitability, the debt level is low because companies with high profitability have more internal funding sources. Companies prefer to use internal sources of funds or internal funding rather than external funding. High company profitability will have a positive impact or can increase firm value. This result is also in line with the results of research conducted by Manurung et al., (2014); Hasbi (2015); Ozazuwa \& Ahmad (2015); Winarto (2015); and Zeb and Rashid (2016).

The Effect of CR (X2) on DER (Y1) on property \& real estate companies listed on the IDX for the period 20132017 Based on Table 2, it is known that the significance value is $0,000<0,05$, so the hypothesis (H5) is accepted, this result shows the effect of the significance of the CR on DER on the property \& real estate companies listed on the IDX. Beta value 0.331 shows a positive direction, this value means that CR has a positive effect on DER. If the CR in property \& real estate companies increases, then the DER for property \& real estate companies listed on the IDX decreases or is contradictory. 
This result is in line with the pecking order theory which states that a company with a high level of liquidity, the level of short-term liabilities is low because companies with high liquidity are able to fulfill and pay off all their shortterm liabilities on time. Liquidity is expected to have a positive relationship with the firm value because the higher the liquidity, the fulfillment of short-term obligations is met and that will increase market confidence. This result is also in line with the results of research conducted by Cheung et al., (2015), Vo \& Hong (2016); Shammakhi \& Azita (2016), and Arggawal \& Purna (2017).

Table 3

ANOVA

ANOVAb

\begin{tabular}{|rl|r|r|r|r|r|}
\hline \multicolumn{1}{|c|}{} & \multicolumn{1}{c|}{ Sum of } & & & & \\
\hline 1 & Squares & df & Mean Square & F & Sig. \\
\hline & Regression & 83,227 & 3 & 27,742 & 22,394 &, $000^{\mathrm{a}}$ \\
& Residual & 156,092 & 126 & 1,239 & & \\
& Total & 239,319 & 129 & & & \\
\hline
\end{tabular}

a. Predictors: (Constant), DER, ROE, CR

b. Dependent Variable: PBV

The results of the $\mathrm{F}$ test obtained showed an $\mathrm{F}$ value of 22,394 with a significance of $0,000<0,05$ (significance level used). This shows that ROE, CR, and DER have a simultaneous effect and significance on PBV.

Table 4

Multiple Regression II

Coefficients

\begin{tabular}{|c|c|c|c|c|c|c|}
\hline \multirow{2}{*}{\multicolumn{2}{|c|}{ Model }} & \multicolumn{2}{|c|}{$\begin{array}{l}\text { Unstandardized } \\
\text { Coefficients }\end{array}$} & \multirow{2}{*}{$\begin{array}{l}\text { Standardized } \\
\text { Coeff icients } \\
\text { Beta }\end{array}$} & \multirow[b]{2}{*}{$\mathrm{t}$} & \multirow[b]{2}{*}{ Sig. } \\
\hline & & $\mathrm{B}$ & Std. Error & & & \\
\hline \multirow[t]{4}{*}{1} & (Constant) & ,671 &, 336 & & 1,998 &, 048 \\
\hline & ROE & ,083 & ,012 &, 534 & 7,138 &, 000 \\
\hline & CR &, 114 &, 044 &, 141 & 2,612 & ,026 \\
\hline & DER & ,026 & 013 & ,009 & 2,028 & ,039 \\
\hline
\end{tabular}

a. Dependent Variable: PBV

The Effect of ROE (X1) on PBV (Y2) on property \& real estate companies listed on the Stock Exchange for the period 2013-2017 Based on Table 4, it is known that the significance value is $0,000<0,05$, so the hypothesis (H1) is accepted, this result shows that there is a significant effect between ROE on PBV on property \& real estate companies listed on the IDX. The beta value of 0.534 shows a positive direction, this value means that ROE has a positive effect on PBV. If the ROE in property \& real estate companies increases, the PBV for property \& real estate companies listed on the IDX will increase as well, and vice versa.

The trade-off theory assumes that the company's capital structure is the result of trade-offs from tax profits by using debt with costs that will arise as a result of using the debt. The essence of the trade-off theory in capital structure is to balance the benefits and sacrifices that arise as a result of using debt, if it has greater benefits, then the additional debt is still permitted, but if the sacrifice is due to the use of debt, then the debt is not allowed. If the management of the company is able to increase the value of shares, the firm value will also increase, but if the debt changes, then the capital structure will also change. Changes in capital structure will be beneficial for shareholders if the firm value increases. This result is also in line with the results of research conducted by Winarto (2015); Hasbi (2015); Zeb \& Rashid (2016); Asif \& Bilal (2016); and Rizki et al., (2018).

The Effect of CR (X2) on PBV (Y2) on property \& real estate companies listed on the IDX for the period 20132017 Based on Table 4, it is known that the significance value is $0.026<0.05$, then the hypothesis $(\mathrm{H} 2)$ is accepted,

Putra, I. G. W. R., \& Sedana, I. B. P. (2019). Capital structure as a mediation variable: Profitability and liquidity on company value in real estate companies in Indonesia stock exchange. International Research Journal of Management, IT and Social Sciences, 6(4), 62-72. https://doi.org/10.21744/irjmis.v6n4.640 
this result shows the effect of the significance of the CR on PBV on the property \& real estate companies listed on the IDX. Beta value 0.141 shows a positive direction, this value means that CR has a positive effect on PBV. If the CR in property \& real estate companies increases, the PBV for property \& real estate companies listed on the IDX will increase as well, and vice versa.

Companies with high profitability will be more likely to use reasonable or relatively lower capital structure and the company's operational activities use profits earned and balanced with the use of appropriate capital structures. The trade-off theory assumes that companies may choose to make loans to receive benefits from interest payments on these loans which will save tax costs, by following this theory profitability is expected to have a positive relationship with the capital structure. This result is also in line with the results of research conducted by Masnoon \& Anwar (2012), Ukaegbu \& Oino (2014); Liang et al., (2014); Acaravci (2015); Chadha \& Sharma (2015); Alipour et al., (2015); and Wasim et al., (2016).

The Effect of DER (Y1) on PBV (Y2) on property \& real estate companies listed on the Stock Exchange for the period 2013-2017 Based on Table 4, it is known that the significance value is $0.039<0.05$, then the hypothesis (H5) is accepted, this result shows that there is a significant effect between DER on PBV on property \& real estate companies listed on the IDX. Beta value 0.009 shows a positive direction, this value means that DER has a positive effect on PBV. The better the DER in the property \& real estate company listed on the IDX, the better the PBV of the company.

The trade-off theory states that every company that has high liquidity is advised to take loans to prevent directors from taking or using current assets owned by the company for personal purposes, which implicitly shows that liquidity has a positive relationship with the capital structure. The greater the comparison between current assets and current debt, the higher the company's ability to cover its current liabilities. This result is also in line with the results of research conducted by Ukaegbu \& Oino (2014); Wahab \& Ramli (2014); and Alipour et al., (2015).

\section{Direct Effects, Indirect Effects, and Total Effects}

Based on the results of path analysis, the direct effect, indirect effect, and total effect of the model that has been made can be calculated. Calculation of direct effect, indirect effect, and total effect can be seen in the following table:

Table 5

Direct Effects, Indirect Effects, and Total Effects

\begin{tabular}{|c|c|c|}
\hline & Coefficients & Sig. \\
\hline \multicolumn{3}{|l|}{ Direct: } \\
\hline $\mathrm{ROE} \rightarrow \mathrm{PBV}$ & 0,534 & 0,000 \\
\hline CURRENT $\rightarrow$ PBV & 0,141 & 0,026 \\
\hline $\mathrm{DER} \rightarrow \mathrm{PBV}$ & 0,009 & 0,039 \\
\hline $\mathrm{ROE} \rightarrow \mathrm{DER}$ & 0,083 & 0.002 \\
\hline CURRENT $\rightarrow$ DER & 0,331 & 0,000 \\
\hline \multicolumn{3}{|l|}{ Indirect: } \\
\hline $\mathrm{ROE} \rightarrow \mathrm{DER} \rightarrow \mathrm{PBV}$ & $(0,083) \times(0,009)=0,000$ & \\
\hline CURRENT $\rightarrow$ DER $\rightarrow$ PBV & $(0,331) \times(0,009)=0,002$ & \\
\hline \multicolumn{3}{|l|}{ Total: } \\
\hline $\begin{array}{l}\mathrm{ROE} \rightarrow \mathrm{PBV} \\
(\mathrm{ROE} \rightarrow \mathrm{DER} \rightarrow \mathrm{PBV})\end{array}$ & $(0,534)+(0,000)=0,534$ & \\
\hline $\begin{array}{l}\text { CURRENT } \rightarrow \text { PBV } \\
(\mathrm{CURRENT} \rightarrow \text { DER } \rightarrow \text { PBV) }\end{array}$ & $(0,141)+(0,002)=0,143$ & \\
\hline
\end{tabular}

Secondary Data, 2019

Based on Table 5, it can be explained that the Profitability variable directly affects the Corporate Value of 0.534 , Profitability has an indirect effect on Corporate Values through the Capital Structure of 0,000 so that the effect of total Profitability on Firm value is 0.534 . Based on Table 5, it can be explained that the Liquidity variable has a direct effect on Firm value of 0.141 , Liquidity has an indirect effect on Firm value through Capital Structure of 0.002 so that the effect of total liquidity on Firm value is 0.143 . 
Model Validation

$$
\begin{aligned}
\mathrm{R}^{2} \mathrm{~m}=1-\left(\mathrm{e}_{1}\right)^{2} & \left(\mathrm{e}_{2}\right)^{2} \\
& =1-(0,932)^{2}(0,807)^{2} \\
& =0,434
\end{aligned}
$$

Variation of data that is affected by the model is $43.4 \%$ meaning that the information contained in the data is $43.4 \%$ can be explained by the model, while the remaining $56.6 \%$ is explained by other variables outside the model.

\section{Sobel Test}

The Sobel test in this study is used to determine the indirect effect of Profitability (X1) on Firm Value (Y2) through Capital Structure (Y1) and Liquidity (X2) against Firm Value (Y2) through Capital Structure (Y1). If the $\mathrm{Z}_{\text {count }}$ value is greater than 1.96 (with a confidence level of 95\%), then the mediation variable is assessed to significantly mediate the relationship between the independent variable and the dependent variable. The test results of the effect of Profitability (X1) and Liquidity (X2) on the Firm Value (Y2) through Capital Structure (Y1) are presented in the following table.

Table 6

Sobel Test

\begin{tabular}{lcc}
\hline \multicolumn{1}{c}{ Information } & Z value & P value \\
\hline Profitability> Capital Structure> Company Value & 2,22 & .025 \\
Liquidity $>$ Capital Structure $>$ Company Value & 7,50 & .000 \\
\hline Data Prim
\end{tabular}

Data Primer, 2019

The results of the calculation of the first Sobel test are the effect of profitability (X1) on firm value (Y2) through the capital structure (Y1) obtained by the calculation value of 2.22. $\mathrm{Z}_{\text {count }}$ is greater than 1.96 which means that there is an influence of exogenous variables on endogenous variables through mediation. These results indicate that the results of tabulation $\mathrm{Z1}=2.22$ which mean the capital structure (Y1) significantly mediates the effect of profitability (X1) on firm value (Y2).

The result of the calculation of the second Sobel test is the effect of liquidity (X2) on the firm value (Y2) through the capital structure (Y1) obtained by the calculated value of $7.50 . \mathrm{Z}_{\text {count }}$ is greater than 1.96 which means that there is an influence of exogenous variables on endogenous variables through mediation. These results indicate that the results of tabulation $\mathrm{Z2}=7.50$ which mean the capital structure (Y1) significantly mediates the effect of liquidity (X2) on firm value (Y2).

\section{The Effect of Profitability on Firm value through Capital Structure}

The Sobel test results show that Capital Structure is able to mediate the effect of Profitability on Firm value on Property \& Real Estate Companies listed on the Stock Exchange for the period 2013-2017. The results of the calculation of the Sobel test influence Profitability as measured by return on equity against Firm value as measured by price book value through Capital Structure as measured by the debt-equity ratio obtained by the value of $\mathrm{Z}_{\text {count }}$ at 2.22 . $\mathrm{Z}_{\text {count }}$ is greater than 1.96 (95 percent confidence level), so it can be concluded that the Capital Structure as measured by a debt-equity ratio is able to mediate the effect of Profitability as measured by return on equity on Firm value as measured by price book value. The better and the right management company uses debt, it will increase profitability which will have an impact on increasing the firm value itself, because the use of appropriate and efficient debt will provide a large return on returns to shareholders and increase shareholder confidence in the company.

The Effect of Liquidity on Firm value through Capital Structure

The Sobel test results show that the Capital Structure is able to mediate the effect of Liquidity on Firm value on Property \& Real Estate Companies listed on the Stock Exchange for the period 2013-2017. The calculation of the Sobel test effect of liquidity as measured by the current ratio (X2) on the firm value measured by price book value (Y2) through the capital structure measured by debt-equity ratio (Y1) obtained a calculated value of 7.50 . $\mathrm{Z}_{\text {count }}$ is greater

Putra, I. G. W. R., \& Sedana, I. B. P. (2019). Capital structure as a mediation variable: Profitability and liquidity on company value in real estate companies in Indonesia stock exchange. International Research Journal of Management, IT and Social Sciences, 6(4), 62-72. https://doi.org/10.21744/irjmis.v6n4.640 
than 1.96 (95 percent confidence level), so it can be concluded that the capital structure as measured by the debt-equity ratio (Y1) is able to mediate the effect of liquidity as measured by the current ratio (X2) on firm value as measured by the price book value (Y2). Companies that are able to use long-term debt efficiently will have an impact on good liquidity turnover, where companies in meeting their short-term and long-term obligations will not experience obstacles in fulfilling their obligations. This will also affect the firm value, because companies that are able to fulfill short-term and long-term obligations in a timely manner, the shareholders have a high level of trust in the company so that it will increase the firm value.

\section{Conclusion}

The results of this study provide information that the three variables affect the firm value, including profitability, liquidity, and capital structure. The results of data analysis in this study indicate that there is a significant positive effect between profitability and firm value, which means that high profitability has a good effect on firm value. In addition to profitability, the results in this study also show that liquidity has a positive and significant effect on firm value, which means increasing liquidity will increase the firm value, as well as the capital structure that has a positive and significant influence on firm value, where appropriate funding decisions will affect the value of a company.

Another finding in this study is the ability of capital structure variables to mediate profitability and liquidity against firm value. The results of data analysis in this study indicate that the capital structure is able to mediate profitability and liquidity against firm value, this can be seen from the results of the Sobel test which shows results exceeding the specified level of trust.

The results of this study can be used to contribute ideas to investors and companies as a consideration in making further decisions. For investors, this research is expected to provide information related to investment decision making so that investors are able to make appropriate, effective and efficient decisions and for companies, how the level of profitability, liquidity, and capital structure of a company can influence investors to invest in combination with the value of a company.

Companies in the property \& real estate sector that are listed on the IDX are advised to further increase their Profitability, Liquidity and Capital Stress to increase Company Value through improving company performance by increasing company profits which will later become an attraction for investors to invest, and determine the right and effective funding decisions to increase the firm value.

\section{Research Limitation}

The limitations of this study lie in the variables under study, namely this study only concerns the variables of profitability, liquidity, capital structure, and corporate value. In further research, it is suggested to examine how profitability variables mediate the capital structure of firm value or how liquidity variables mediate the capital structure of firm value in accordance with existing theories and empirical evidence.

\section{Conflict of interest statement and funding sources}

The authors declared that they have no competing interest.

\section{Statement of authorship}

The authors have a responsibility for the conception and design of the study. The authors have approved the final article.

\section{Acknowledgments}

The authors would like to thank the Editor of IRJMIS for their valuable time, support, and advice in completing the current study. 


\section{References}

Ab Wahab, S. N. A., \& Ramli, N. A. (2013). Determinants of Capital Structure: An Empirical Investigation of Malaysian Listed Government Linked Companies (GLCs). Available at SSRN 2364238.

Abu Mouamer, F. M. (2011). The determinants of capital structure of Palestine-listed companies. The Journal of Risk Finance, 12(3), 226-241. https://doi.org/10.1108/15265941111136969

Acaravci, S. K. (2015). The determinants of capital structure: Evidence from the Turkish manufacturing sector. International Journal of Economics and Financial Issues, 5(1), 158-171.

Aggarwal, D., \& Padhan, P. C. (2017). Impact of capital structure on firm value: evidence from Indian Hospitality Industry. Theoretical Economics Letters, 7(04), 982. https://doi.org/10.4236/tel.2017.74067

Aghara, V. N. O., Nwaizugbo, I. C., Oparah, P. C., \& Ifeanyichukwu, C. D. (2018). Sales promotion as a leverage strategy for improving sales and profitability in alcohol beverage industry. International Research Journal of Management, IT and Social Sciences, 5(4), 18-25. https://doi.org/10.21744/irjmis.v5n4.245

Agustina, L., \& Baroroh, N. (2016). The relationship between Enterprise Risk Management (ERM) and firm value mediated through the financial performance. Review of Integrative Business and Economics Research, 5(1), 128.

Ahmed Sheikh, N., \& Wang, Z. (2011). Determinants of capital structure: An empirical study of firms in manufacturing industry of Pakistan. Managerial Finance, 37(2), 117-133. https://doi.org/10.1108/03074351111103668

Alipour, M., Mohammadi, M. F. S., \& Derakhshan, H. (2015). Determinants of capital structure: an empirical study of firms in Iran. International Journal of Law and Management, 57(1), 53-83. https://doi.org/10.1108/IJLMA-012013-0004

Asif, A., \& Aziz, B. (2016). Impact of Capital structure on Firm value creation-Evidence from the Cement sector of Pakistan. International Journal of Research in Finance and Marketing, 6(6), 231-245.

Brigham, E. F., \& Daves, P. R. (2014). Intermediate financial management. Cengage Learning.

Chadha, S., \& Sharma, A. K. (2015). Determinants of capital structure: an empirical evaluation from India. Journal of Advances in Management Research, 12(1), 3-14. https://doi.org/10.1108/JAMR-08-2014-0051

Cheung, W. M., Chung, R., \& Fung, S. (2015). The effects of stock liquidity on firm value and corporate governance: Endogeneity and the REIT experiment. Journal of Corporate Finance, 35, 211-231. https://doi.org/10.1016/j.jcorpfin.2015.09.001

Dewi, I. G. A. A. O., \& Dewi, I. G. A. A. P. (2017). Corporate social responsibility, green banking, and going concern on banking company in Indonesia stock exchange. International Journal of Social Sciences and Humanities, 1(3), 118-134. https://doi.org/10.29332/ijssh.v1n3.65

Gharaibeh, A. (2014). Capital structure, Liquidity, and Stock returns. European Scientific Journal, ESJ, 10(25). http://dx.doi.org/10.19044/esj.2014.v10n25p\%25p

Hasbi, H. (2015). Islamic microfinance institution: the capital structure, growth, performance and value of firm in Indonesia. Procedia-Social and Behavioral Sciences, $1073-1080$. https://doi.org/10.1016/j.sbspro.2015.11.143

Heryanto, A. (1995). What Does Post-Modernism Do in Contemporary Indonesia?. SOJOURN: Journal of Social Issues in Southeast Asia, 33-44.

Husnan, S. (2016). Manajemen Keuangan : Teori dan Penerapan (Edisi 4). Yogyakarta : BPFE Yogyakarta.

Kumar, M. S., \& Babu, P. C. (2016). Determinants of capital structure of select edible oil firms in india. Indian Journal of Commerce and Management Studies, 7(1), 12.

Liang, J., Fang Li, L., \& Song, H. S. (2014). An explanation of capital structure of China's listed property firms. Property Management, 32(1), 4-15. https://doi.org/10.1108/PM-02-2013-0012

Loncan, T. R., \& Caldeira, J. F. (2014). Capital structure, cash holdings and firm value: a study of Brazilian listed firms. Revista Contabilidade \& Finanças, 25(64), 46-59.

M'ng, J. C. P., Rahman, M., \& Sannacy, S. (2017). The determinants of capital structure: Evidence from public listed companies in Malaysia, Singapore and Thailand. Cogent Economics \& Finance, 5(1), 1418609.

Malinic, D., Dencic-Mihajlov, K., \& Ljubenovic, E. (2013). The determinants of capital structure in emerging capital markets: Evidence from Serbia. European Research Studies, 16(2), 98.

Manurung, S. D. (2014). The Influence of Capital Structure on Profitability and Firm Value (a Study on Food and Beverage Companies Listed in Indonesia Stock Exchange 2010-2012 Period). Jurnal Administrasi Bisnis, 7(2).

Masnoon, M., \& Anwar, F. (2012). Capital structure Determinants of KSE listed Pharmaceutical companies.

Mostarac, E., \& Petrovic, S. (2013). Determinants of capital structure of Croatian enterprises before and during the financial crisis. utms Journal of Economics, 4(2), 153-162.

Putra, I. G. W. R., \& Sedana, I. B. P. (2019). Capital structure as a mediation variable: Profitability and liquidity on company value in real estate companies in Indonesia stock exchange. International Research Journal of Management, IT and Social Sciences, 6(4), 62-72. https://doi.org/10.21744/irjmis.v6n4.640 
Mota, J. H., \& Moreira, A. C. (2017). Determinants of the capital structure of Portuguese firms with investments in Angola. South African Journal of Economic and Management Sciences, 20(1), 1-11.

Osazuwa, N. P., \& Che-Ahmad, A. (2016). The moderating effect of profitability and leverage on the relationship between eco-efficiency and firm value in publicly traded Malaysian firms. Social Responsibility Journal, 12(2), 295-306. https://doi.org/10.1108/SRJ-03-2015-0034

Pattweekongka, S., \& Napompech, K. (2014). Determinants of Capital Structure: Evidence from Thai Lodging Companies. International Journal of Arts \& Sciences, 7(4), 45.

Pramanaswari, A. S. I., \& Yasa, G. W. (2018). Graham \& Dodd theory in stock portfolio performance in LQ 45 index at Indonesia stock exchange. International Research Journal of Management, IT and Social Sciences, 5(6), 52-59. https://doi.org/10.21744/irjmis.v5n6.338

Rizki, A., Lubis, A. F., \& Sadalia, I. (2018). The Influence of Capital Structure to the Firm Value with Profitability As Intervening Variables. KnE Social Sciences, 3(10).

Salehi, M., \& Manesh, N. B. (2012). A study of the roles of firm and country on specific determinates in capital structure: Iranian evidence. International Management Review, 8(2), 51-62.

Sartono, A. (2016). Manajemen Keuangan : Teori dan Aplikasi (Edisi 4). Yogyakarta : BPFE Yogyakarta.

Shah, S. Q., Perveen, S., \& Javed, N. (2013). Determinants of Capital Structure: An Analysis of Cement Industry of Pakistan. International Journal of Information, Business and Management, 5(4), 172.

Shammakhi, H. R., \& Mehrabi, A. (2016). Study the effect of liquidity of stock on stock returns in the companies listed in Tehran stock exchange. International Journal of Economics, Commerce and Management, 4, 12.

Sucuahi, W., \& Cambarihan, J. M. (2016). Influence of profitability to the firm value of diversified companies in the Philippines. Accounting and Finance Research, 5(2), 149-153.

Taddese Lemma, T., \& Negash, M. (2013). Institutional, macroeconomic and firm-specific determinants of capital structure: The African evidence. Management Research Review, 36(11), 1081-1122. https://doi.org/10.1108/MRR09-2012-0201

Ukaegbu, B., \& Oino, I. (2014). The determinants of capital structure: A comparison of financial and non-financial firms in a regulated developing country-Nigeria. African Journal of Economic and Management Studies, 5(3), 341368. https://doi.org/10.1108/AJEMS-11-2012-0072

Van Horne, C. J., \& Wachowicz, J. M. JR. 2013. Prinsip-prinsip Manajemen Keuangan.

Vo, X. V., \& Hồng Thu, B. (2013). Liquidity, Liquidity Risk and Stock Returns-Evidence from Vietnam. Liquidity Risk and Stock Returns-Evidence from Vietnam (November 1, 2013).

Wasim, S. S., Alam, S., \& Saeed, M. (2016). An Empirical Analysis of Capital Structure of KSE-100 Listed Electricity Companies of Pakistan. Global Management Journal for Academic \& Corporate Studies, 6(1), 101.

Winarto, J. (2015). The determinants of manufacturer firm value in Indonesia stock exchange. International Journal of Information, Business and Management, 7(4), 323.

Yanti, N. M. Y. W. A., \& Dwirandra, A. (2019). The effect of profitability in income smoothing practice with good corporate governance and dividend of payout ratio as a moderation variable. International Research Journal of Management, IT and Social Sciences, 6(2), 12-21. https://doi.org/10.21744/irjmis.v6n2.601

Zeb, S., \& Rashid, A. (2016). Impact of Financial Health and Capital Structure on Firm's Value, with Moderating Role of Intangible Assets. Global Management Journal for Academic \& Corporate Studies, 6(1), 37. 